\title{
Exploring the Nutritional Quality Improvement in Cereal Bars Incorporated with Pulp of Guava Cultivars
}

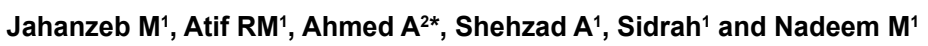 \\ ${ }^{1}$ National Institute of Food Science and Technology, University of Agriculture, Faisalabad \\ ${ }^{2}$ Wheat Research Institute, Ayyub Agricultural Research Institute, Faisalabad
}

\begin{abstract}
Fruits play an important role in human diet because they are dynamic bases of minerals, vitamins and dietary fiber. They are rich sources of iron, phosphorous, calcium, and magnesium and contribute $90 \%$ of dietary vitamin $\mathrm{C}$. Yellow and green fruits are rich in vitamin A (beta carotene) folic acid, niacin and thiamine which are vital for normal functioning of the human body. Due to the high perishability, Guava fruit ripen quickly in a few days after harvesting at room temperature. Due to its delicate nature it cannot be stored for a longer period of time. The surplus quantity of the fruit remains unsold and goes to waste during peak harvest season. Extension in post-harvest shelf life and preservation of guava fruit is the pre-requisite for the economical and efficient utilization of this important fruit commodity in Pakistan. Guava pulp is considered as a rich source of fiber, ash, polyphenols, and sugars. This study was aimed to develop cereal based bars using different varieties of guava pulp from two cultivars (Gola and Surahi) (GP) at different concentrations (10\% and $15 \%)$. Prepared bars were subjected to the proximate analysis. The results demonstrated high moisture, protein and lower level of fat contents in the bars. Bars with guava pulp of Gola cultivar (15\%) showed the high level of moisture ( $6.34 \pm 0.03$ to $6.47 \pm 0.02)$, protein $(4.69 \pm 0.02$ to $4.61 \pm 0.01)$, fiber $(3.85 \pm 0.05$ to $3.84 \pm 0.06)$ and fat $(3.42 \pm 0.05$ to $3.06 \pm 0.03)$ contents. Then the bars were evaluated for sensory acceptance by trained personal. The sensory analysis showed satisfactory acceptance of the bars containing $10 \%$ guava pulp (GP) regarding the aroma, flavor, and textural attributes. The bars containing $15 \%$ GP received satisfactory acceptance regarding to aroma only but their texture was not too good. The bars were stored for 14 days and the effect of storage were studied on the bars.
\end{abstract}

Keywords: GP (Guava pulp); Polyphenols; Sensory analysis; Proximate composition

\section{Introduction}

Guava (Psidium guajava L.) being a climacteric and highly perishable fruit has rapid post-harvest ripening [1]. It is called common man's fruit and also referred as the apple of the tropics and "apple of poor man". Guava has the priority over other fruits due to its high nutritional and commercial values.

Numerous studies have been carried out in order to replace wheat flour with flour made from fruit pulp (dry) in the preparation of bakery products such as biscuits due to economic constraints, business requirements, new consumption trends, and specific eating habits [2,3]. Residues of different fruits can be important source of nutrients to satisfy consumer demand for healthier products. Many food industries are finding ways to add functional ingredients to their products [4]. According to Aquino et al., [2] when fruits and their pulp added to foods. They were able to enhance the taste, texture, aroma, color and nutritional value of the products produced. Santucci et al. [5] stated that the flour mixed with different fruit fractions or using pulp improves not only the nutritional quality of bars but improve their palatability, making them more accepted by consumers.

Currently, the food sector has to deal with a high rate of food waste produced by fruit processing for various products such as jams, juices, ice cream, bakery products, sweets and others. The use of fresh pulp fruits is an important new step for the food industry. Use guava processing waste, such as guava peel, could increase the raw material yield minimizing the problems caused by the disposal of large amount of industrial waste and also expand alternative food production [6]. The Guava as a fruit has not much higher shelf life but when converted to different products the shelf life of the fruit as a new product is increased and thus post-harvest losses are lessened. An economically and technologically feasible alternative would be to produce flour from guava peels in order to either make new products, such as cookies, or partially replace wheat flour to improve the product's nutritional quality since guava has good antioxidant potential and high vitamin $C$ and phenolic compound levels and pigments such as $\beta$-carotene and lycopene [7].

Guava is used in many products to enhance the shelf life and to increase the nutritional value of the product. Guava is being processed into different products e.g. jam, jelly, marmalade, beverages and many other different products. Being a climacteric fruit guava exhibit a rapid rise in rate of respiration and production of ethylene during ripening [8]. Guava fruit shelf life ranges from 2 to 4 days at ambient temperature. Numerous postharvest handling methods including controlled/ modified atmosphere and cold storages have been recommended to extend the storage life and maintain quality of guava fruit. Its delicate nature, short post-harvest life, and susceptibility to chilling injury and diseases, limit the potential for export of guava fruit. Thus, the current research was done to show that the shelf life can be increased by converting guava pulp in cereal based bars. During current study innovative bars filled with Guava pulp was made. It can increase the nutritional value of the cereal bars and introduce a new flavor to the customer.

*Corresponding author: Ahmed A, Wheat Research Institute, Ayyub Agricultura Research Institute, Faisalabad, Pakistan, Tel: +923027131850; E-mail mjahanzeb2296@yahoo.com

Received January 11, 2016; Accepted February 03, 2016; Published February 08, 2016

Citation: Jahanzeb M, Atif RM, Ahmed A, Shehzad A, Sidrah, et al. (2016) Exploring the Nutritional Quality Improvement in Cereal Bars Incorporated with Pulp of Guava Cultivars. J Food Process Technol 7: 567. doi:10.4172/2157-7110.1000567

Copyright: @ 2016 Jahanzeb M, et al. This is an open-access article distributed under the terms of the Creative Commons Attribution License, which permits unrestricted use, distribution, and reproduction in any medium, provided the original author and source are credited. 


\section{Materials and Method}

\section{Procurement of raw material}

Guava (Psidium guajava L.) fruit was purchased from the Samundari, Faisalabad Pakistan. The fruits were washed under running clean tap water, then the fruits were cut into small pieces and blanched to inactivate the enzyme of guava, then after it, the fruits were put into the fine pulper for pulp extraction. Material preparation and the physicochemical analysis were performed at the Laboratory of Food Safety at Faculty of Food, Nutrition and Home Sciences, University of Agriculture, Faisalabad, Pakistan.

\section{Preparation of bars}

Weighed pulp was filled in plastic bottles then stored at freezing temperature. The pulp was stored for about one week to get the desired hard texture for filling in the bars. The pulp was again weighed to calculate the yield, packed in sealed glass containers stored at room temperature for $12 \mathrm{~h}$ prior to bar preparation. Then the pulp was added into the dough sheets to make Guava bars (Table 1).

\section{Proximate analysis}

Moisture: Moisture content of the bars was determined with slight modifications in methods used by Florina. Weighed samples were placed in the hot air oven for $5-6$ hours at $95^{\circ} \mathrm{C}$.

Moisture $(\%)=\frac{\text { Wt. of original sample }- \text { Wt. of dried sample } \times 100}{\text { Wt. of original sample }}$

Ash: The samples were analyzed for total ash with some difference in Florina.

$$
\text { Ash }=\frac{\text { Wt. of ash } \times 100}{\text { Wt. of sample }}
$$

Fat: The crude fat contents of samples was determined by following procedure described in AOAC [9] method No. 30-10.01.

$$
\text { Crude Fat }(\%)=\frac{\text { Wt. of fat } \times 100}{\text { Wt. of sample }}
$$

Crude protein: The crude protein contents in sample was estimated according to the Kjeldahl's method as described in Sackey.

$$
\begin{aligned}
& \text { Nitrogen }(\%)=\frac{\text { Vol. of } \mathrm{H}_{2} \mathrm{SO}_{4} \times 250 \times 0.0014 \times 100}{\text { Wt. of sample } \times \text { Vol. of sample }} \\
& \text { Total protein }(\%)=\% \text { Nitrogen } \times 5.57
\end{aligned}
$$

Fiber: Fiber percentage was calculated according to Sackey Augustina Sackle and Kwaw Emmanuel method with minor modification. The percentage of crude fiber was calculated after igniting the samples according to the expression given below:

Crude fiber $(\%)=\frac{\text { Wt. of residue left }- \text { Wt. of ash } \times 100}{\text { Wt. of original sample }}$

Total sugars (Reducing and non-reducing): Total sugars was found by Lane and Eynon described by Ranganna with some modification.

\begin{tabular}{|c|c|}
\hline Treatments & Concentration \\
\hline $\mathbf{T}_{0}$ & Controlled \\
\hline $\mathbf{T}_{1}$ & Guava Pulp (Gola) $(10 \%)$ \\
\hline $\mathbf{T}_{1}{ }^{\prime}$ & Guava Pulp (Gola) $(15 \%)$ \\
\hline $\mathbf{T}_{2}$ & Guava Pulp (Surahi) $(10 \%)$ \\
\hline $\mathbf{T}_{2}{ }^{\prime}$ & Guava Pulp (Surahi) (15\%) \\
\hline \multicolumn{2}{|c|}{ Table 1: Treatment plan. } \\
\hline
\end{tabular}

$\%$ Total Sugars $=\frac{\text { Fehling solution factor } \times \text { dilution factor } \times 100}{\text { Titration value }}$

Ascorbic acid: Ascorbic acid content was determined by indophenol's titration method described by AOAC [9] with some modifications.

$$
\begin{aligned}
& \text { Ascorbic acid mg } / 100 \mathrm{ml}=\frac{1 \times \mathrm{R} \times \mathrm{V} \times 100}{\mathrm{R}_{1} \times \mathrm{W} \times \mathrm{V}_{1}} \\
& \mathrm{l}=\text { Constant } \\
& \mathrm{R}_{1}=\mathrm{ml} \text { of dye used for standard solution } \\
& \mathrm{R}=\text { Dye used during sample } \\
& \mathrm{V}=\text { Volume of sample diluted with oxalic acid solution } \\
& \mathrm{W}=\text { Weight of sample }
\end{aligned}
$$

Sensory analysis of guava bars: Sensory analysis of product was performed by a panel of trained judges. Evaluation was done on 9 hedonic scale.

\section{Results and Discussion}

The graphical depiction of compositional result shows parameters one by one. There are few studies in the literature on the use of fruits pulps for making bars. No studies were identified in the literature reporting data of proximate composition of guava pulp; only a few studies on fresh fruit, guava powder and guava pomace residues were found. The lack of data on guava pulp may explain the differences observed between the data analyzed and those available in the literature because the flour undergoes prior physical processes, such as heating, which may change its physical and chemical attributes.

\section{Moisture}

It is obvious from the results that there was a gradual increase in moisture during the storage. The pulp concentration had a significant effect on bars, while the storage had the non-significant effect. Owing to high moisture content, increase in pulp concentration increases moisture value. This is because the pulp has high concentrations of the moisture that's why the moisture content is increasing by increasing the pulp concentration.

The moisture content of the guava bars was $6.28 \%$ to $6.40 \%$, which was increased during the storage period because the plastic containers tends to impermeable to the moisture and thus the moisture of the bars were retained.

In a study by Munhoz et al. [10], the moisture content obtained from guava pulp was $12.55 \%$, and the moisture content of flour obtained from the pulp with guava peel was $13.24 \%$; these results are higher than those obtained in the present study. It was found the average moisture content of $9.72 \%$ in guava (Psidium guajava L) flour; a value that is somewhat comparable to the present study. In graph series 1 shows storage days (Figures 1 and 2).

\section{Fiber}

Storage impact was also had non-significant effect on crude fiber. The content of crude fiber remained almost same during whole storage period. As the concentration of guava pulp is different, the percentage of crude fiber contents depends upon the concentration of pulp used in different treatments. It is depicted from the results that guava pulp is the richest source of dietary fiber. 


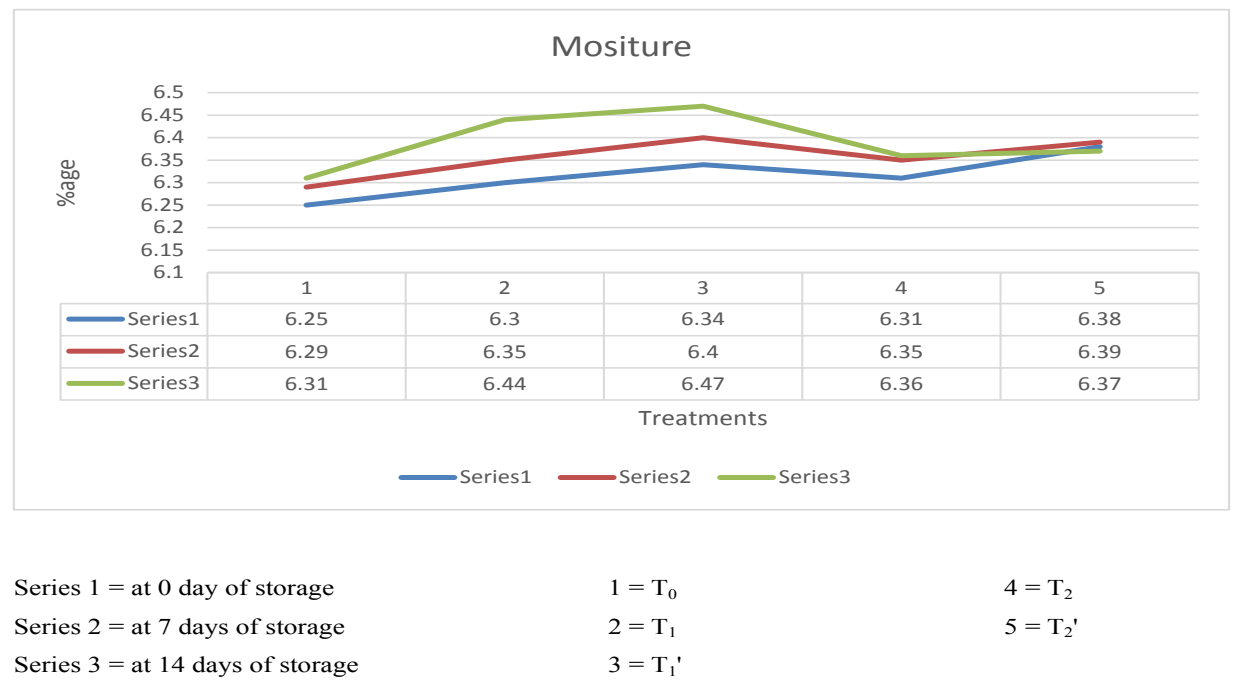

Figure 1: Graph for moisture content.

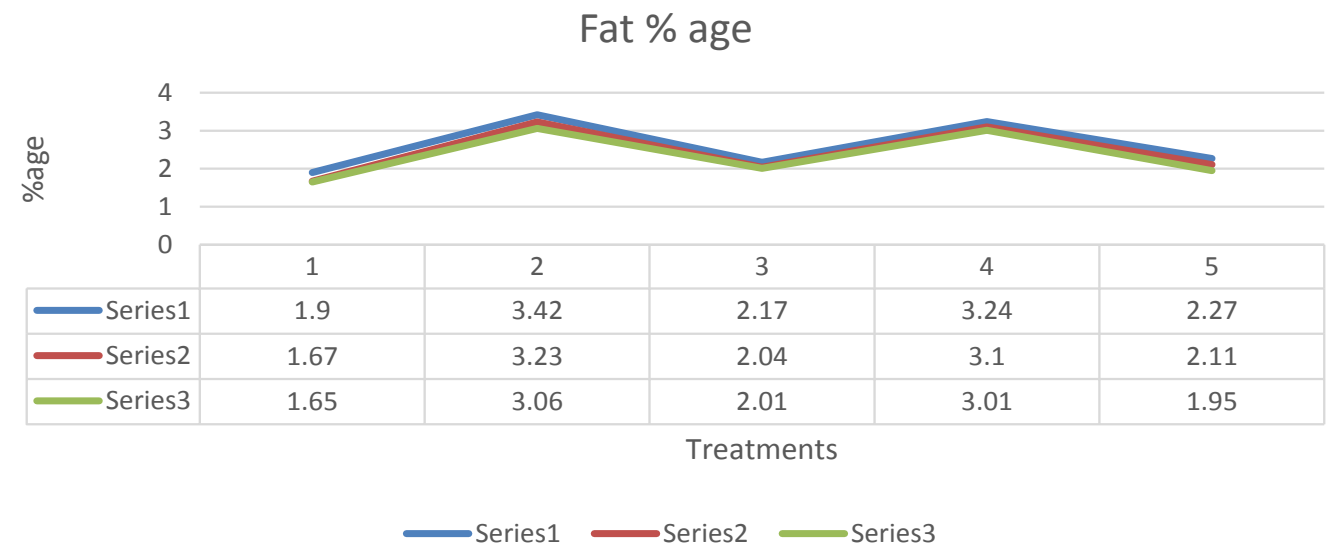

Figure 2: Graph for fat content.

It is vivid from the results that there is significant difference in crude fiber contents for different treatments of bars. Means for crude fiber of different samples (Graph) demonstrated that $\mathrm{T}_{0}$ showed the lowest value $0.52 \%$ of fiber content. The highest value for crude fiber contents $3.52 \%$ were found in $\mathrm{T}_{1}{ }^{\prime}$. It is depicted from the results that guava pulp is the richest source of dietary fiber so bars have more fiber content than control. Leelavanthi and Tzia [11] prepared high fiber bars and found that dietary fiber content that was about three times higher than the control bars (Figure 3).

\section{Protein}

Analysis of variance for protein contents of different treatments during storage has been given in graph. It is obvious from the results that there is significant difference in protein contents for different treatments of bars. Means for protein contents of different treatments demonstrated that $\mathrm{T}_{2}$ ' showed the highest value (4.65\%) of protein content. The lowest protein contents $(2.90 \%)$ were found in $\mathrm{T}_{0}$. Protein contents increased as we added guava pulp at different concentrations [12].
Means for protein contents of different treatments demonstrated that $\mathrm{T}_{2}$ ' showed the highest value $(4.65 \%)$ of protein content. The lowest protein contents $(2.90 \%)$ were found in $\mathrm{T}_{0}$. Protein contents increased as we added guava pulp at different concentrations (Figure 4).

\section{Ash}

The effect of pulp showed that the ash content was increasing in the bars. As the guava pulp has more fiber percentage thus, the ash content is increasing by addition of the pulp. Gola has the more ash percentage as compare to Surahi. Mean values (graph) for ash contents of different treatments showed the lowest value $(0.69 \%)$ of ash content by $\mathrm{T}_{0}$ while the highest value of ash contents $3.23 \%$ was found in treatment $\mathrm{T}_{1}$ '. While $\mathrm{T}_{1}, \mathrm{~T}_{2}$ and $\mathrm{T}_{2}{ }^{\prime}$ had $3.16 \%, 2.32 \%$ and $4.24 \%$ ash respectively [13] (Figure 5).

\section{Total sugars}

It is evident from the results that there was a gradual increase in total sugars of guava bars with increasing in storage periods. The mean 


\section{Fiber Percentage}

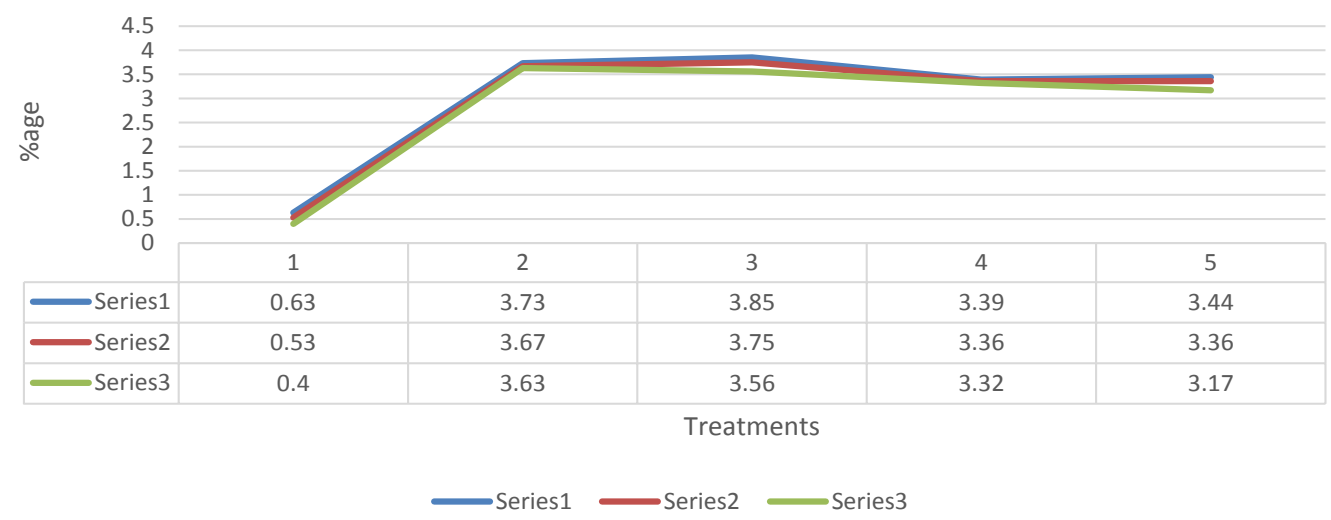

Figure 3: Graph for fiber content

Crude Protein

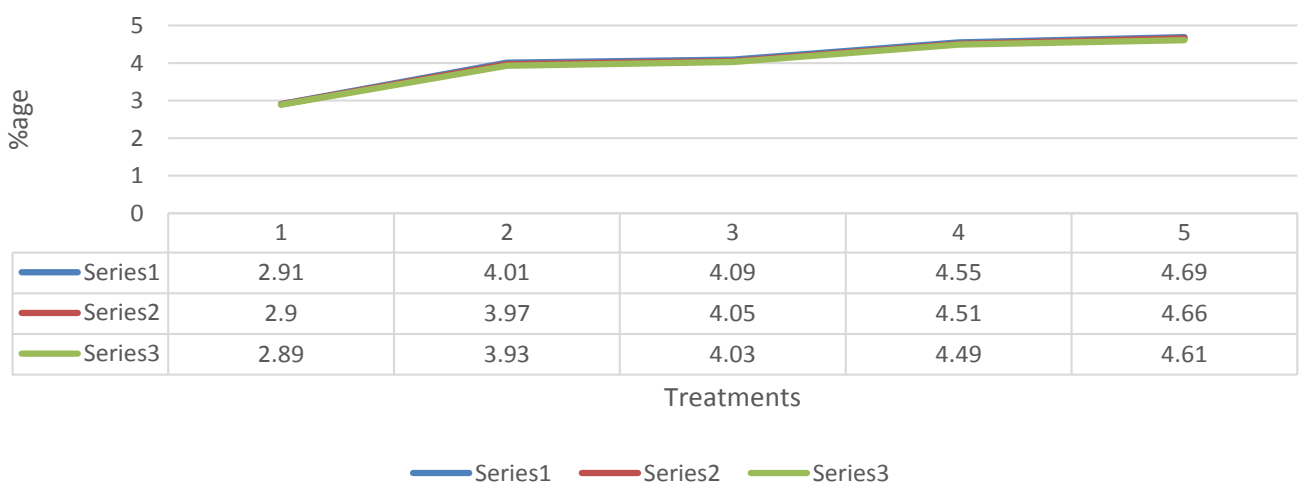

Figure 4: Graph for crude protein content.

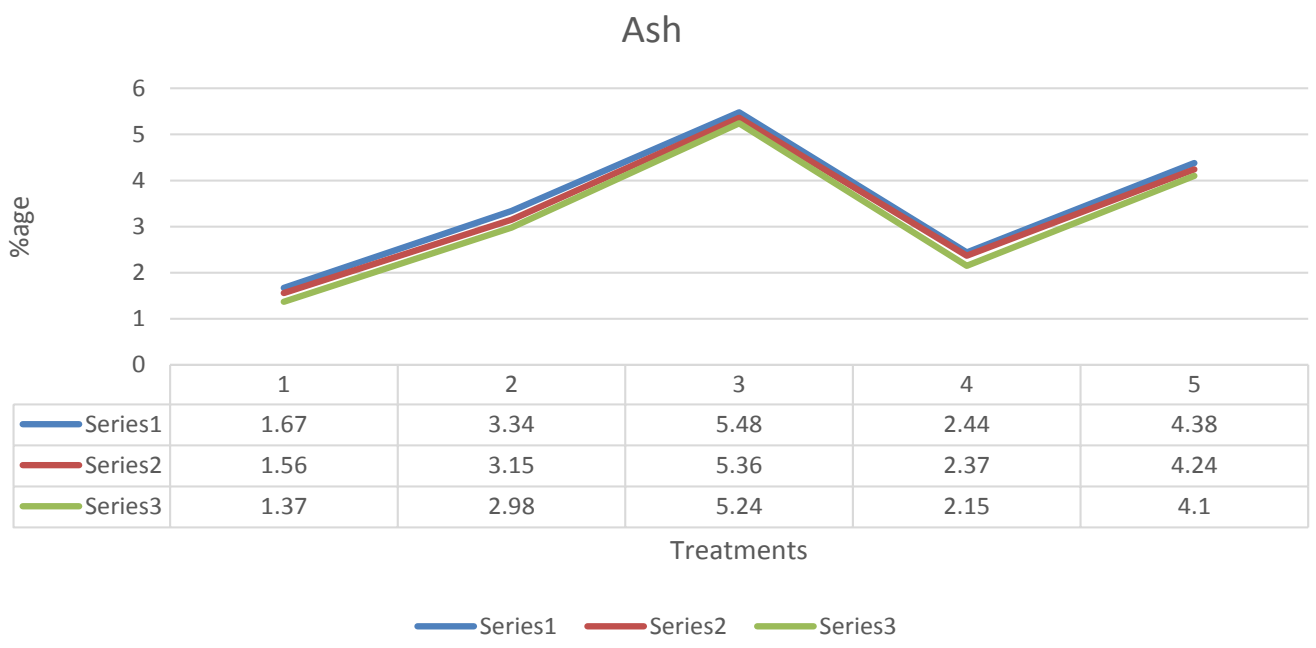

Figure 5: Graph for ash content. 
Citation: Jahanzeb M, Atif RM, Ahmed A, Shehzad A, Sidrah, et al. (2016) Exploring the Nutritional Quality Improvement in Cereal Bars Incorporated with Pulp of Guava Cultivars. J Food Process Technol 7: 567. doi:10.4172/2157-7110.1000567

Page 5 of 7

values of total sugars for storage periods increased from 46.62 to 49.15 at 0 to 14 days. The increase in TSS and total sugars would be attributed to the conversion of starch and other insoluble carbohydrates into sugars. Mean values regarding the treatments of total sugars of guava bars were 43.49, 45.63, 46.22, 51.13 and 52.48 for $\mathrm{T}_{0}, \mathrm{~T}_{1}, \mathrm{~T}_{1}{ }^{\prime}, \mathrm{T}_{2}$ and $\mathrm{T}_{2}{ }^{\prime}$ respectively [13-15]. The lowest score was observed for $\mathrm{T}_{0}$ and the highest score was in case of $\mathrm{T}_{2}$ '. It is apparent from the results that there was a gradual increase in total sugars of guava bars with increasing in storage periods. The mean values of total sugars for storage periods increased from 46.62 to 49.15 at 0 to 14 days (Figure 6).

\section{Total phenolic content (TPC)}

TPC was decreasing as the storage days increasing because it is a phenolic content and thus, sensitive to storage. TPC was increasing by increasing the concentration of the pulp. Amongst treatments, a similar behavior was shown by all the treatments indicating a steady decrease in total phenolic content during the course of storage. The maximum decrease in the total phenolic content value was noted for $\mathrm{T}_{0}$ as it varied from 131.67 to 107.67 and 94.67 at 0 to $7^{\text {th }}$ and $14^{\text {th }}$ day, respectively (Figures 7-9).

\section{Conclusion}

It is apparent from mean squares regarding the ascorbic acid of treated guava that significant variations were recorded for the effect of treatments and storage period. Moreover, their interaction was also found to be momentous. As the vitamin- $\mathrm{C}$ (ascorbic acid) is a sensitive compound thus the ascorbic acid activity is decreasing as the storage days increasing. From means, it is inferred that the maximum value for ascorbic acid in the treated guava sample was recorded in $\mathrm{T}_{2}$ and $\mathrm{T}_{1}{ }^{\prime}$ as $141.92 \mathrm{mg} / 100 \mathrm{~g}$ and $142 \mathrm{mg} / 100 \mathrm{~g}$ followed by $138.83 \mathrm{mg} / 100 \mathrm{~g}$ in $\mathrm{T}_{2}$ ', respectively.

Total Sugars

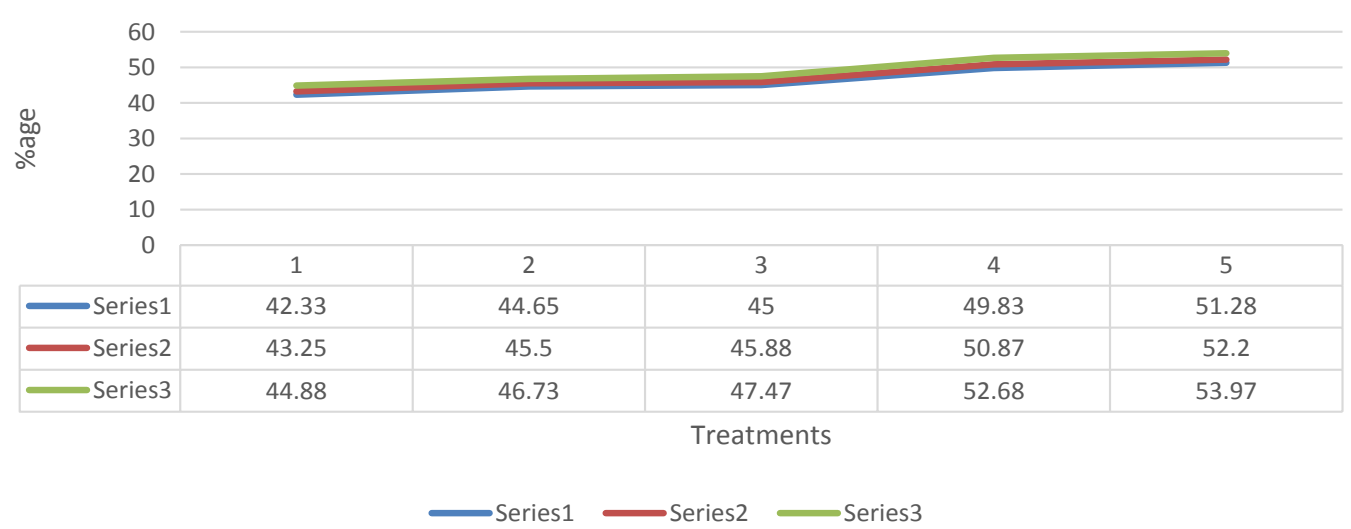

Figure 6: Graph for total sugars.

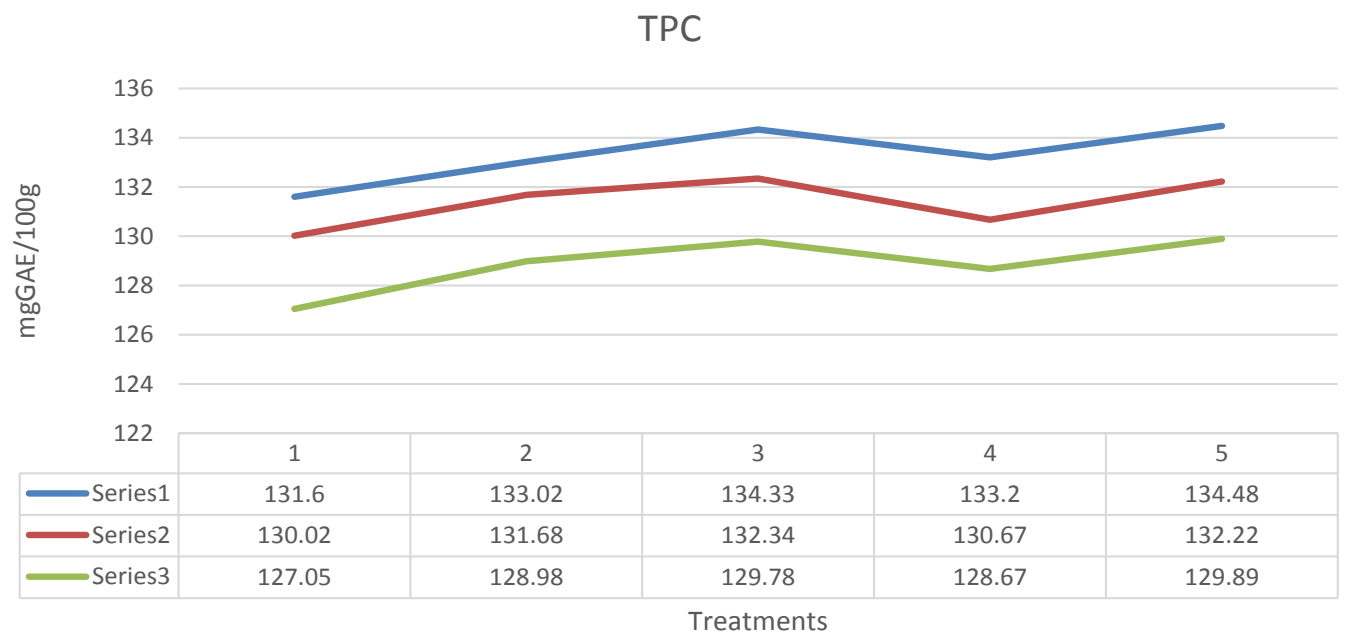

Figure 7: Graph for TPC content. 
Citation: Jahanzeb M, Atif RM, Ahmed A, Shehzad A, Sidrah, et al. (2016) Exploring the Nutritional Quality Improvement in Cereal Bars Incorporated with Pulp of Guava Cultivars. J Food Process Technol 7: 567. doi:10.4172/2157-7110.1000567

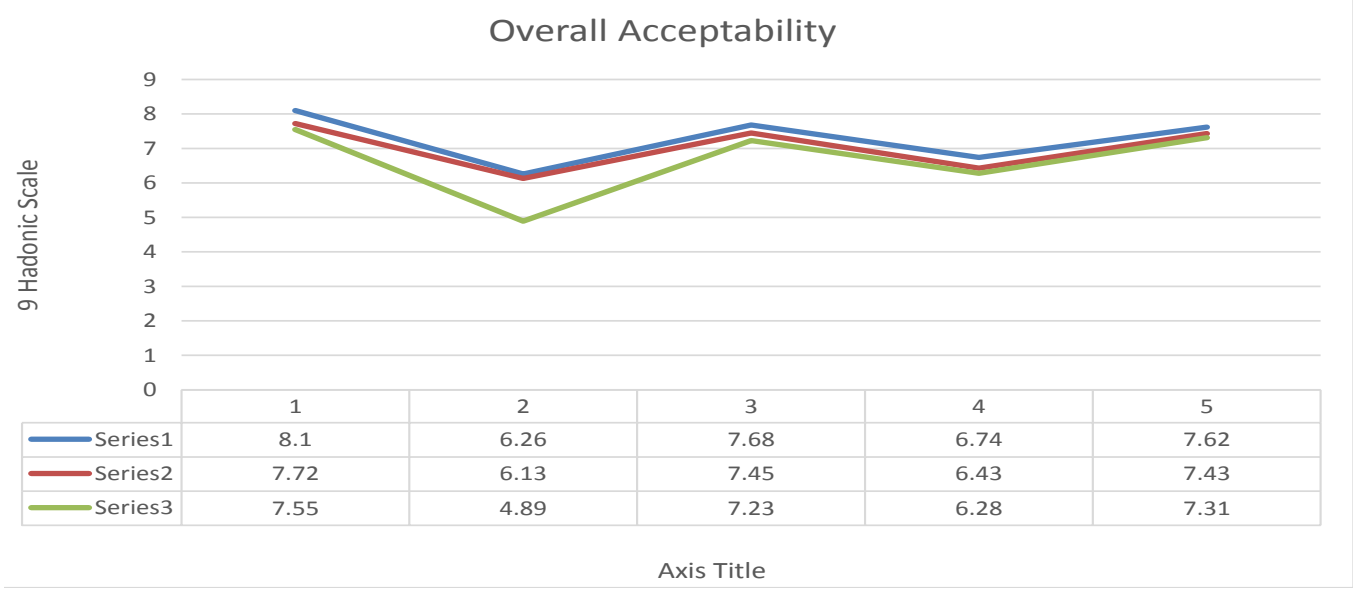

Figure 8: Graph for overall acceptability.

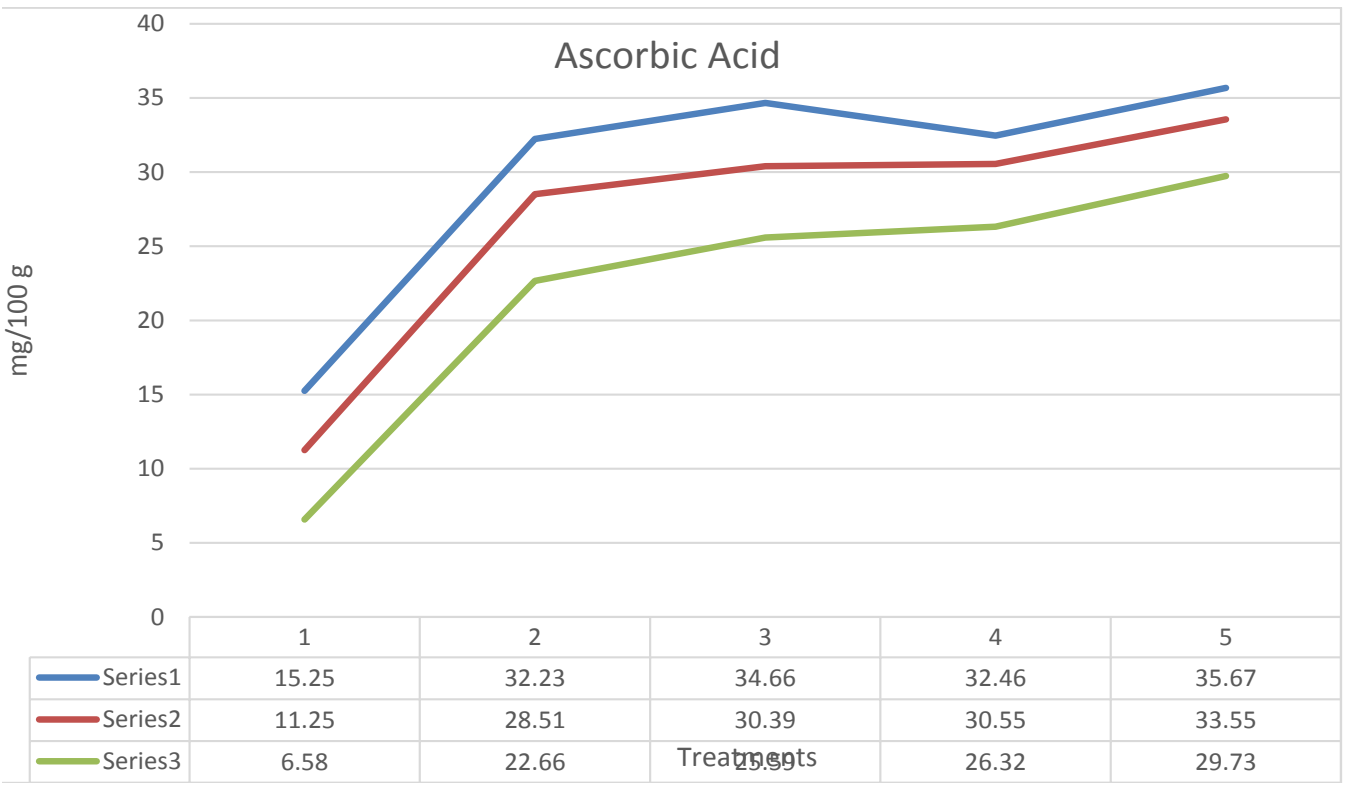

Figure 9: Graph for ascorbic acid

\section{References}

1. Bashir HA, Abu-Goukh AA (2003) Compositional changes during guava fruit ripening. Food chem 80: 557-563

2. Aquino AC, Leo KMM, Figueiredo AVD, Castro AA (2010) Physical-chemical and sensory acceptance of cookies like cookies made with waste acerola meal. $\mathrm{J}$ Inst Adolfo Lutz 69: 379-386.

3. Perez PMP, Germani R (2007) Elaboration of crackers, high in dietary fiber, using eggplant flour (Solanum melongena L). Food Sci and Tech 27: 186-192.

4. Assisi LM, Zavareze ER, Raünz AL, Dias ARG, Gutkoski LC (2009) Nutritional, technological and sensory properties of cookies with wheat flour substitute for oatmeal or parboiled rice flour. Food and Nutrition 20: 15-24.

5. Santucci MCC, Alvim ID, Faria EV, Sgarbieri VC (2003) Effect of enrichment biscuits type water and salt with yeast extract (Saccharomyces sp.). Sci and Tech Food 23: 441-446.

6. Kobori CN, Jorge N (2005) Characterization of some seed oils of fruits for utilization of industrial waste. Sci and Agrotecnologia 29: 1008-1014.
7. Oliveira DS, Aquino PP, Ribeiro SM, Proenca RP, Pinheiro-Phillips HMP (2011) Vitamin C, carotenoids, total phenolic and antioxidant activity of guava, mango and papaya coming from Ceasa of Minas Gerais. Acta Scientiarum: Health Sci 33: 89-98.

8. Mercado-Silva E, Bautista PB, Velasco MG (1998) Fruit development, harvest index and ripening changes of guavas produced in central Mexico. Postharvest Biology and Tech 13: 143-150.

9. AOAC (2006) Association of Official Analytical Chemists. Official methods of analysis of AOAC. AOAC press, Arlington, VA, USA.

10. Munhoz CL, Sanjinez-Argandoña EJ, Smith Junior MS (2010) Guava pectin extraction dehydrated. Food Sci and Tech 30: 119-125

11. Leelavathi K, Tzia C (2011) Use of endoxylanase treated cereal brans for development of dietary fibre enriched cakes. Innovative Food Sci and Emerging Tech 13: 207-214.

12. Fernandes AF, Pereira J, Germani R, Oiano-Neto J (2008) Efeito da substituição parcial da farinha de trigo por farinha de casca de batata (Solanum tuberosum Lineu). Food Sci and Tech 28: 56-65. 
Citation: Jahanzeb M, Atif RM, Ahmed A, Shehzad A, Sidrah, et al. (2016) Exploring the Nutritional Quality Improvement in Cereal Bars Incorporated with Pulp of Guava Cultivars. J Food Process Technol 7: 567. doi:10.4172/2157-7110.1000567

Page 7 of 7

13. Ishimoto FY, Harada AI, Branco IG, Conceição WAS, Coutinho MR (2007) Alternative use of the bark of yellow passion fruit (Passiflora edulis var. FlavicarpaDeg.) for the production of biscuits. Magazine Exact and Natural Sciences.

14. Mauro AK, Silva VLM, Freitas MCJ (2010) Phisical, chemical, and sensorial characterization of cookies made with kale stalk flour (KSF) and spinach stalk flour (SSF) rich in nourishing fiber. Food Science and Techonology 30: 719-728.

15. Ghafar MFA, Prasad KN, Weng KK, Al.Ismai (2010) Flavonoid, hesperidine, total phenolic Contents and antioxidant activities from citrus species. African J of Biotech 9: 326-330. 